\author{
A. S. Hamralaine, H. Benhassaini, M. D. Miara, M. Ait Hammou \& O. \\ Hamralaine
}

\title{
Species diversity, chorology and conservation of the lichen flora in Tessala Mountains forest (North-West Algeria)
}

\begin{abstract}
Hamralaine, A. S., Benhassaini, H., Miara, M. D., Ait Hammou, M. \& Hamralaine, O.: Species diversity, chorology and conservation of the lichen flora in Tessala Mountains forest (NorthWest Algeria). — Fl. Medit. 29: 75-91. 2019. — ISSN: 1120-4052 printed, 2240-4538 online.

This study is a first investigation of the lichen flora of the Tessala Mountains green oak forest in northwestern Algeria. Field research using stratified sampling method allowed us to propose a first checklist of the lichen flora of this region containing 53 taxa with taxonomic, chorological and biogeographical data in North-West Africa (Algeria, Morocco and Tunisia) of each of them. Among these lichens, 3 taxa are cited for the first time for the NW Africa. Comments on some interesting species are added, especially those with wide distribution reported currently only in Algeria, which are to be found in neighboring countries (Morocco, Tunisia). Finally, 17 taxa present in our list are protected by the Algerian law. The forest of Tessala Mountains must urgently benefit from an official protection status in order to preserve this lichen biodiversity of proven interest.
\end{abstract}

Key words: checklist, inventory, North-West Africa, Quercus ilex subsp. ballota, Sidi Bel Abbès.

\section{Introduction}

In North Africa, the lichen flora is mainly Mediterranean with a very high endemism (Werner 1955). It is essentially the region of folded mountains at the northwestern of the continent dominated by the Atlas Mountains with a Mediterranean climate (White 1996).

The study of lichen of Algeria is a relatively old (Amrani \& al. 2015) dating back to the written first contribution in 1799 by René Desfontaines in his Flora Atlantica (1798-1799). Although there is no real flora of lichens in Algeria. Thus, the current knowledge of lichens in Algeria is still mainly based on the multitude of works carried out during the colonial period including: Montagne (1838); Durieu de Maisonneuve \& Montagne (1846); Nylander (1854); Flagey (1892, 1895, 1896); Werner (1938, 1949); Faurel \& al. (1951, 1953). Since the independence of the country, several studies have been interested in lichens: Ozenda \& Clauzade (1970); Hertel (1971, 1987); Schwarz (1976); Leuckert \& al. (1977); Clauzade \& Roux (1984); Esnault (1985); Esnault \& Roux (1987). The work of the 
natives on this flora began with the study of Zouaoui (1989) on the lichens of Akfadou, then Semadi \& al. (1997) in the region of Annaba and that of Rahali (2003) in the region of Algiers. Subsequently, some studies have been published mainly in the west of the country Bendaikha (2006); Ait Hammou \& al. (2008, 2011, 2013); Khedim (2012); Khedim \& al. $(2013,2018)$. Some studies have also been published in the east of the country (Rebbas \& al. 2011; Serradj \& al. 2013; Slimani \& al. 2013; Ali Ahmed \& al. 2018). Finally, we have to underline the very important recently published synthesis studies (Ait Hammou \& al. 2014; Amrani \& al. 2015; Amrani \& al. 2018).

Specifically, Algeria, the largest country in Africa $\left(2381741 \mathrm{~km}^{2}\right)$ is rather poorly explored from a lichenological point of view and almost certainly contains many lichen taxa yet to be discovered (Ait Hammou 2014; Amrani \& al. 2015).

The data on the Algerian lichen flora is still very incomplete and the revision of the lichen flora of Algeria must be encouraged (Khedim \& al. 2018).

The region of the Mount of Tessala in western Algeria which containing a very rich flora (Bouiadjra \& al. 2011) is floristically one of the least explored areas of the country (Saidi 2017). Indeed, the lichen flora of this region remains totally unknown and to our knowledge, no research study on lichens of this region has been published.

So, this study was considered in the main objective to bring new data to the country's lichen flora through the proposal of a first checklist of lichens of the Tessala Mountain, then to look for possible novelties within this list in particular in terms of chorology of taxa.

\section{The Study area}

The forest of Tessala Mountain also called "forest of El Attouche" is located in the North West of the country (Fig. 1) between three wilayas "provences": Sidi Bel Abbès, Oran and Ain Témouchent. It is part of the commune of Tessala located at $20 \mathrm{~km}$ from Sidi Bel Abbès city and covers an area of 2036 ha. The altitudes vary between 200 and $600 \mathrm{~m}$ a.s.l. on the dominant medium Mountains and up to $1060 \mathrm{~m}$ on the top of the Mountain (Bouiadjra \& al. 2011).

The forest of Tessala includes vegetation dominated by holm oak. It is contains the following formations: preforests of Quercus ilex subsp. ballota (Desf.) Samp. and Q. coccifera L. in the East and South-East; scrubs formations of Q. coccifera, Calycotome intermedia Rchb.f. and Chamaerops humilis L. in the West and Southwest; degraded scrubs of Calycotome intermedia, Chamaerops humilis and Ampelodesmos mauritanicus T.Durand $\&$ Schinz in the center, East and in the extreme North-East; a clear forest of Pinus halepensis Mill. and Quercus ilex subsp. ballota on the high peaks (Saidi 2017).

The climate of the Tessala Mountains is Mediterranean as well as all the West Northern Algeria. It is characterized by concentrated rains during the cold period (autumn and winter, monthly average $=40.9 \mathrm{~mm}$ ) and a marked drought during the warmer months (summer, monthly average $=1.76 \mathrm{~mm}$ ). The bioclimatic levels vary according to the altitude from the arid to the sub-humid while the dominant level is the semi-arid (Ferka-Zazou 2006). 


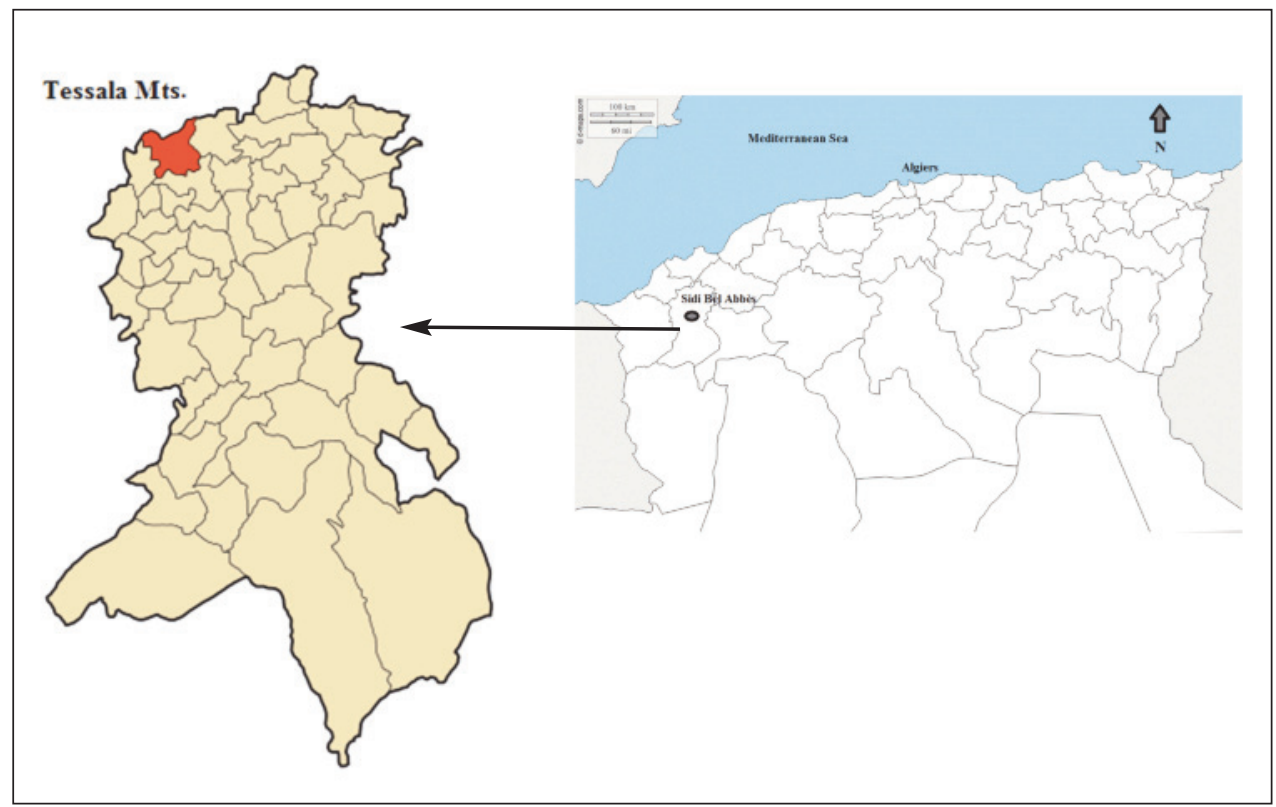

Fig.1. Location map of the study area.

\section{Materials and Methods}

Field work was started in 2013 using a stratified sampling method (Gounot 1969). Initially, we consulted the aerial photography of the region in order to explore the relief. The layer of vegetation being homogeneous (stands of holm oaks); we proceeded to the definition of the different environments of the site "strata": e.g. altitudes, exposure, topography. Then, in the field, we went through the zones previously defined. This allowed us to carry out sufficiently large lichen samplings in nine stations of one hectare $\left(10000 \mathrm{~m}^{2}\right)$ each "square $100 \mathrm{~m}$ long and $100 \mathrm{~m}$ wide". At these stations, survey corresponds to a part of a tree, mainly the trunk and the branches. According to Roux (1990), a maximum number of species are recorded in the field and sufficient samples are collected, especially those difficult to detect with the naked eye, and each phorophyt was georeferenced while the several parameters were recorded (height, circumference, position, density, slope, exposure, altitude, $\mathrm{pH}$, sunshine). Within each station, terricolous, saxicolous and muscicolous lichens were also considered. Several special floras have been used for the botanical identification of taxa harvested in the field, including: Ozenda \& Clauzade (1970); Boistel (1986); Hale (1990); Kirschbaum \& Wirth (1997); Serusiaux \& al. (2004); Jahns (2007); Aptroot \& Schumm (2008); Krzewicka \& al. (2009); Aptroot (2009) and Haluwyn \& al. (2009, 2012). The nomenclature follows Roux \& coll. (2017), while the collected specimens have been deposited in the herbarium of the laboratory of botany, the University of Tiaret. 
In order to be able to search for possible new taxonomic and chorological novelties, we compare our results with the published works in the NW of Africa (Algeria, Morocco and Tunisia), by using all the available bibliography for Algeria: Durieu de Maisonneuve \& Montagne (1846); Nylander (1854); Jourdan (1867); Flagey (1896); Zablbruckner (1904); Maheu (1928); Bouly de Lesdain (1907, 1911, 1939); Maire \& Senevet (1928); Zahlbruckner (1930, 1931); Werner (1931, 1955); Reichert (1937); Dubuis \& Faurel (1945); Faurel \& al. (1951, 1953); Semadi (1989); Djebar \& Fradjia (1992); Djellil (1989); Egea (1996); Boutabia (2000); Hamrlaine (2013); Bendaikha (2006); Mosbah (2007); Ait Hammou \& al. (2008, 2011, 2014); Rebbas \& al. (2011); Fadel \& al. (2012); Khedim (2012); Slimani \& al. (2013); Serradj (2013); Khedim \& al. (2018); Ali Ahmed \& Al (2018) and Amrani \& al. (2018). For neighboring countries, we used mainly: Seaward (1996); El Mokni \& al. (2015); Guttová \& al. (2015) for Tunisia and Ajaj \& al. (2013) for Morocco.

\section{GPS limitation of sampled stations}

\section{Station 1}

$35^{\circ} 16^{\prime} 19.1$ '” $00^{\circ} 47^{\prime} 12.9$ '”

$35^{\circ} 16^{\prime} 15.1$ 'N $0^{\circ} 47^{\prime} 06.5^{\prime \prime} \mathrm{W}$

$35^{\circ} 16^{\prime} 10.5^{\prime \prime} \mathrm{N} 0^{\circ} 47^{\prime} 12.4^{\prime \prime} \mathrm{W}$

$35^{\circ} 16^{\prime} 15.6^{\prime \prime} \mathrm{N} 0^{\circ} 47^{\prime} 17.5^{\prime \prime} \mathrm{W}$

\section{Station 2}

$35^{\circ} 16^{\prime} 20.7^{\prime \prime} \mathrm{N} 0^{\circ} 47^{\prime} 17.5^{\prime \prime} \mathrm{W}$

$35^{\circ} 16^{\prime} 26.7^{\prime \prime} \mathrm{N} 0^{\circ} 47^{\prime} 20.7^{\prime \prime} \mathrm{W}$

$35^{\circ} 16^{\prime} 24.3$ ”'N $0^{\circ} 47^{\prime} 28.5^{\prime \prime} \mathrm{W}$

$35^{\circ} 16^{\prime} 19.3$ ”'N $0{ }^{\circ} 47^{\prime} 23.4$ ' W

\section{Station 3}

$35^{\circ} 16^{\prime} 23.4^{\prime \prime} \mathrm{N} 0^{\circ} 47^{\prime} 14.2^{\prime \prime} \mathrm{W}$

$35^{\circ} 16^{\prime} 27.9^{\prime \prime} \mathrm{N} 0^{\circ} 47^{\prime} 18.2^{\prime \prime} \mathrm{W}$

$35^{\circ} 16^{\prime} 32.5^{\prime \prime} \mathrm{N} 0^{\circ} 47^{\prime} 13.0^{\prime \prime} \mathrm{W}$

$35^{\circ} 16^{\prime} 29.3$ ”'N $0^{\circ} 47^{\prime} 05.4^{\prime \prime} \mathrm{W}$

\section{Station 4}

$35^{\circ} 16^{\prime} 34.3$ ”N $0^{\circ} 47^{\prime} 04.0$ ” W

$35^{\circ} 16^{\prime} 27.4$ 'N $0^{\circ} 47^{\prime} 05.1$ ' W

$35^{\circ} 16^{\prime} 25.0^{\prime \prime} \mathrm{N} 0^{\circ} 46^{\prime} 56.6^{\prime \prime} \mathrm{W}$

$35^{\circ} 16^{\prime} 31.6$ ”'N $0^{\circ} 46^{\prime} 54.2^{\prime \prime} \mathrm{W}$ 
Station 5

$35^{\circ} 17^{\prime} 04.7^{\prime \prime} \mathrm{N} 0^{\circ} 47^{\prime} 21.2^{\prime \prime} \mathrm{W}$

$35^{\circ} 17^{\prime} 01.4$ 'N 0॰47'19.7’'W

$35^{\circ} 16^{\prime} 59.7^{\prime} \times \mathrm{N} \mathrm{0} 47^{\circ} 26.0^{\prime \prime} \mathrm{W}$

$35^{\circ} 17^{\prime} 03.4^{\prime \prime} \mathrm{N} 0^{\circ} 47^{\prime} 30.5^{\prime \prime} \mathrm{W}$

\section{Station 6}

35 $17^{\circ} 00.4$ ”N $00^{\circ} 47^{\prime} 32.4^{\prime \prime} \mathrm{W}$

$35^{\circ} 16^{\prime} 55.3^{\prime \prime} \mathrm{N} 0^{\circ} 47^{\prime} 34.5^{\prime \prime} \mathrm{W}$

$35^{\circ} 16^{\prime} 57.1^{\prime \prime} \mathrm{N} 0^{\circ} 47^{\prime} 42.2^{\prime \prime} \mathrm{W}$

$35^{\circ} 17^{\prime} 02.5^{\prime \prime} \mathrm{N} 0^{\circ} 47^{\prime} 43.4^{\prime \prime} \mathrm{W}$

\section{Station 7}

$35^{\circ} 16^{\prime} 59.5^{\prime \prime} \mathrm{N} 0^{\circ} 47^{\prime} 49.8^{\prime \prime} \mathrm{W}$

$35^{\circ} 17^{\prime} 05.1^{\prime \prime} \mathrm{N} 0^{\circ} 47^{\prime} 46.2^{\prime \prime} \mathrm{W}$

$35^{\circ} 17^{\prime} 03.2^{\prime \prime} \mathrm{N} 0^{\circ} 47^{\prime} 58.7^{\prime \prime} \mathrm{W}$

$35^{\circ} 17^{\prime} 08.1^{\prime \prime} \mathrm{N} 0^{\circ} 47^{\prime} 54.4^{\prime \prime} \mathrm{W}$

\section{Station 8}

35 16 '51.4'"N 047'46.4'”W

$35^{\circ} 16^{\prime} 44.3^{\prime \prime} \mathrm{N} 0^{\circ} 47^{\prime} 43.3^{\prime \prime} \mathrm{W}$

$35^{\circ} 16^{\prime} 42.5^{\prime \prime} \mathrm{N} 0^{\circ} 47^{\prime} 52.6^{\prime \prime} \mathrm{W}$

$35^{\circ} 16^{\prime} 52.3^{\prime \prime} \mathrm{N} 0^{\circ} 47^{\prime} 53.6^{\prime \prime} \mathrm{W}$

\section{Station 9}

35 16 '47.4”'N 047'28.9'” W

$35^{\circ} 16^{\prime} 52.4$ ”'N 0॰47'24.4”'W

$35^{\circ} 16^{\prime} 49.2^{\prime \prime} \mathrm{N} \mathrm{0} 47^{\prime} 16.6^{\prime \prime} \mathrm{W}$

$35^{\circ} 16^{\prime} 43.2^{\prime \prime} \mathrm{N} 0^{\circ} 47^{\prime} 21.0^{\prime \prime} \mathrm{W}$

\section{List of substrates and their abbreviations:}

Co: Corticolous on Quercus ilex subsp. ballota (holm oak)

Te: Terricolous

Sa: Saxicolous

$\mathrm{Mu}$ : Muscicolous

\section{Results and discussion}

\section{Checklist of lichen and lichenicolous fungi of Tessala Mountains}

The presented list includes 53 species recorded in the study area and contains the following information: species name, botanical family, station numbers in which the lichen was recorded and substrate "in brackets", information on published data. For each species, 
the known distribution in NW Africa (Algeria, Tunisia, and Morocco) is given with references. The new species reported for the first in NW Africa with asterisks (*):

Amygdalaria continua Brodo \& Hertel

Lecideaceae; 5 (Sa); Published data in NW Africa: Alg, Ait Hammou \& al. (2011); Hamralaine (2013). No data published in Morocco and Tunisia.

Anaptychia ciliaris (L.) Körb. ex A. Massal.

Physciaceae; 1, 2 , 3, 4, 6, 9, 8 (Co); Published data in NW Africa: Alg, Ait Hammou \& al. (2011); Ait Hammou (2013); Bendaikha (2006); Boutabia (2000); Djellil (1989); Hamralaine (2007, 2013); Khedim (2012); Mosbah (2007); Slimani \& al. (2013); Werner (1940, 1949, 1955); Alonso \& Egea (2003); Fadel \& al. (2012); Tun, Seaward (1996); El Mokni \& al. (2015); Mor, Ajaj \& al. (2013).

Buellia coniops (Wahlenb.) Th. Fr.

Caliciaceae; 5 (Sa); Published data in NW Africa: Alg, Ait Hammou \& al. (2011); Hamralaine (2013). No data published in Morocco and Tunisia.

Caloplaca cerina (Ehrh. ex Hedw.) Th. Fr.

Teloschistaceae; 1, 9 (Co); Published data in NW Africa: Alg, Ait Hammou \& al. (2011); Haina \& Bendechach (2004); Hamralaine (2007); Hamralaine (2013); Tun, Seaward (1996), El Mokni \& al. (2015); Mor, Ajaj \& al. (2013).

Caloplaca flavorubescens (Huds.) J.R. Laundon

Teloschistaceae; 4 (Co); Published data in NW Africa: Alg, Egea \& al. (1990); Faurel \& al. (1953); Haina \& Bendechach (2004); Hamralaine (2013); Mor, Ajaj \& al. (2013);

Tun, Guttová \& al. (2015).

Candelariella superdistans (Nyl.) Malme

Candelariaceae; 3 (Co); Published data in NW Africa: Alg, Hamralaine (2013); Nylander (1854); No data published in Morocco and Tunisia.

Collema furfuraceum (Arnold) Du Rietz

Collemataceae; 4, 5, 7 (Co); Published data in NW Africa: Alg, Khedim \& al. (2018); Boutabia, 2000; Djellil (1989); Alonso \& Egea (2003); Haina \& Bendechach (2004); Hamralaine (2007, 2013); Rahali (2003); Semadi (1989); Tun, Seaward (1996), El Mokni \& al. (2015); Mor, Ajaj \& al. (2013).

Evernia prunastri (L.) Ach.

Parmeliaceae; 2, 4, 5, 7, 9 (Co); Published data in NW Africa: Alg, Khedim \& al. (2018); Ait Hammou \& al. (2011); Haina \& Bendechach (2004); Hamralaine (2007, 2013); Khedim (2012); Rahali (2003); Rebbas \& al. (2011); Tun, Seaward (1996), El Mokni \& al. (2015); Mor, Ajaj \& al. (2013).

Flakea papillata O.E. Erikss.

Verrucariaceae; 6 (Co); Published data in NW Africa: Alg, Ait Hammou \& al. (2011); Hamralaine (2013). No data published in Morocco and Tunisia.

Hypogymnia physodes (L.) Nyl. (= Parmelia physodes (L.) Ach.)

Parmeliaceae; 2, 3, 4, 6, 8, 9 (Co); Published data in NW Africa: Alg, Khedim \& al. (2018); Brongniart (1882); Dubuis \& Faurel (1945); Flagey (1896); Haina \& Bendechach (2004); Hamralaine (2013); Mosbah (2007); Nylander (1854); Tun, Seaward (1996), El Mokni \& al. (2015); Mor, Ajaj \& al. (2013). 
Lathagrium auriforme (With.) Otálora, P.M. Jørg. \& Wedin

Collemataceae; 5, 6 (Co, Mu); Published data in NW Africa: Alg, Rebbas \& al. (2011), Slimani \& al. (2013), Amrani \& al. (2018); Tun, Seaward (1996), El Mokni \& al. (2015); Mor, Ajaj \& al. (2013).

\section{Lecanora allophana Nyl.}

Lecanoraceae; 2, 4 (Co); Published data in NW Africa: Alg, Hamralaine (2013); Rebbas \& al. (2011); Rehali (2003); Tun, El Mokni \& al. (2015); Mor, Ajaj \& al. (2013).

Lecanora carpinea (L.) Vainio

Lecanoraceae; 3, 4, 6 (Co); Published data in NW Africa: Alg, Serradj \& al. (2013); Boutabia (2000); Djellil (1989); Flagey (1896); Haina \& Bendechach (2004); Merabti (2008); Mosbah (2007); Rebbas \& al. (2011); Slimani \& al. (2013); Werner (1949, 1955); Tun, Seaward (1996); El Mokni \& al. (2015); Mor, Ajaj \& al. (2013).

Lecanora glabrata (Ach.) Malme

Lecanoraceae; 2, 3, 4, 6, 7, 9 (Co); Published data in NW Africa: Alg, Alonso \& Egea (2003); Flagey (1896); Haina \& Bendechach (2004); Hamralaine (2013); Werner (1940); Mor, Ajaj \& al. (2013).

Lecanora dispersa (Pers.) Sommerf.

Lecanoraceae; 4, 7 (Sa); Published data in NW Africa: Alg, Ait Hammou \& al. (2011); Bendaikha (2006); Egea \& al. (1990); Flagey (1896); Haina \& Bendechach (2004); Hamralaine (2007, 2013); Merabti (2008); Mosbah (2007); Rahali (2003); Semadi (1989); Werner (1949, 1955); Tun, Seaward (1996); Mor, Ajaj \& al. (2013).

Lecanora pulicaris (Pers.) Ach.

Lecanoraceae; 1, 2, 3, 4, 7, 8, 9 (Co); Published data in NW Africa: Alg, Bendaikha (2006); Djellil (1989); Flagey (1896); Haina \& Bendechach (2004); Hamralaine (2013); Semadi (1989); Rahali (2003); Mor, Ajaj \& al. (2013).

*Lecanora praesistens Nyl.

Lecanoraceae; 4, 3 (Co); No data published in NW Africa.

Lecanora rupicola (L.) Zahlbr.

Lecanoraceae; 6 (Sa); Published data in NW Africa: Alg, Djellil (1989); Dubuis \& Faurel (1945); Flagey (1896); Haina \& Bendechach (2004); Hamralaine (2013); Nylander (1854); Steiner (1902); Tun, Seaward (1996), El Mokni \& al. (2015); Mor, Ajaj \& al. (2013).

Lecidea exigua Chaub.

Lecideaceae; 5, 6 (Co); Published data in NW Africa: Alg, Boutabia \& al. (2015), Amrani $\&$ al. (2018). No data published in Morocco and Tunisia.

Lecidella euphorea (Flörke) Hertel

Lecanoraceae; 6 (Co); Published data in NW Africa: Alg, Djellil (1989); Flagey (1896); Haina \& Bendechach (2004); Hamralaine (2013); Merabti (2008); Rahali (2003); Semadi (1989); Tun, Seaward (1996); Mor, Ajaj \& al. (2013).

Lepraria incana (L.) Ach.

Stereocaulaceae; 2, 3, 4, 6, 7, 8, 9 (Co); Published data in NW Africa: Alg, Serradj (2013); Bendaikha (2006); Alonso \& Egea (2003); Haina \& Bendechach (2004); Hamralaine (2013); Khedim (2012); Merabti (2008); Rebbas \& al. (2011); Rahali (2003); Semadi (1989); Slimani \& al. (2013); Tun, El Mokni \& al. (2015). 
Lichenomphalia umbellifera (L.: Fr.) Redhead, Lutzoni, Moncalvo \& Vilgalys Hygrophoraceae; 6, 7 (Co, Te); Published data in NW Africa: Alg, Khedim \& al. (2018); Hamralaine (2013). No data published in Morocco and Tunisia.

*Multiclavula vernalis (Schwein.) R.H. Petersen

Clavulinaceae; 5 (Mu); No data published in NW Africa.

Opegrapha varia Pers.

Roccellaceae; 3, 4, 9 (Co); Published data in NW Africa: Alg, Bendaikha (2006); Haina \& Bendechach (2004); Hamralaine (2013); Merabti (2008); Tun, Seaward (1996).

Parmelia horrescens (Taylor) Elix \& Hale

Parmeliaceae; 2, 3, 4, 5, 6, 7, 8 (Co); Published data in NW Africa: Alg, Djellil (1989); Haina \& Bendechach (2004); Hamralaine (2013); Werner (1955); Tun, El Mokni \& al. (2015).

Parmelina carporrhizans (Taylor) Poelt \& Vězda

Parmeliaceae; 1, 3, 4, 5, 6, 7, 9 (Co); Published data in NW Africa: Alg, Slimani \& al. (2013); Hamralaine (2013); Mor, Ajaj \& al. (2013).

Parmelina quercina (Willd.) Hale

Parmeliaceae; 2, 5 (Co); Published data in NW Africa: Alg, Ait Hammou \& al. (2011); Hamralaine (2013). No data published in Morocco and Tunisia.

Phaeophyscia hirsuta (Merschk.) Moberg

Physciaceae; 1, 2, 3, 4, 6, 7, 8, 9 (Co); Published data in NW Africa: Alg, Boutabia (2000); Alonso \& Egea (2003); Fadel \& al. (2012); Hamralaine (2013); Tun, Seaward (1996), El Mokni \& al. (2015); Mor, Ajaj \& al. (2013).

Phaeophyscia orbicularis (Neck.) Moberg

Physciaceae; 2, 3, 4, 5, 6, 7 (Co); Published data in NW Africa: Alg, Khedim \& al. (2018); Boutabia (2000); Flagey (1896); Haina \& Bendechach (2004); Hamralaine (2013); Mosbah (2007); Semadi (1989); Tun, Seaward (1996), El Mokni \& al. (2015); Mor, Ajaj \& al. (2013).

Phlyctis argena (Sprengel) Flotow

Phlyctidaceae; 4, 5, 7 (Co); Published data in NW Africa: Alg, Serradj \& al. (2013); Djellil (1989); Fadel \& al. (2012); Haina \& Bendechach (2004); Hamralaine (2013); Merabti (2008); Slimani \& al. (2013); Tun, El Mokni \& al. (2015); Mor, Ajaj \& al. (2013).

Physcia adscendens (Fr.) H. Olivier

Physciaceae; 1, 2, 3, 4, 5, 6, 7, 8, 9 (Co); Published data in NW Africa: Alg, Bendaikha (2006); Boutabia (2000); Fadel \& al. (2012); Egea \& al. (1990); Egea \& Llimona (1991); Alonso \& Egea (2003); Haina \& Bendechach (2004); Hamralaine (2013); Khedim (2012); Merabti (2008); Rahali (2003); Rebbas \& al. (2011); Semadi (1989); Slimani \& al. (2013). No data published in Morocco and Tunisia.

Physcia albinea (Ach.) Nyl.

Physciaceae; 5 (Sa); Published data in NW Africa: Alg, Ait Hammou \& al. (2011); Bendaikha (2006); Boutabia (2000); Haina \& Bendechach (2004); Hamralaine (2007, 2003); Reichert (1937); Semadi (1989); Werner (1940); Mor, Ajaj \& al. (2013).

Physcia biziana (A. Massal.) Zahlbr.

Physciaceae; 1, 2, 8, 9 (Co); Published data in NW Africa: Alg, Khedim \& al. (2018); Bendaikha (2006); Boutabia (2000); Haina \& Bendechach (2004); Hamralaine (2013); Reichert (1937); Semadi (1989); Werner (1940); Tun, Seaward (1996); Guttová \& al. (2015); Mor, Ajaj \& al. (2013). 
Physcia aipolia (Ehrht.) E. Humb.

Physciaceae; 2, 3, 4, 6, 7, 9 (Co); Published data in NW Africa: Alg, Khedim \& al. (2018); Ait Hammou \& al. (2011); Djellil (1989); Alonso \& Egea (2003); Haina \& Bendechach (2004); Hamralaine (2007, 2013); Khedim (2012); Mosbah (2007); Semadi (1989); Slimani \& al. (2013); Tun, El Mokni \& al. (2015); Mor, Ajaj \& al. (2013).

Physcia caesia (Höffm.) Fürnrohr

Physciaceae; 5, 6, 7 (Sa); Published data in NW Africa: Alg, Egea \& Llimona (1991); Flagey (1896); Haina \& Bendechach (2004); Hamralaine (2013); Nylander (1854); Tun, Seaward (1996), El Mokni \& al. (2015); Mor, Ajaj \& al. (2013).

Physcia dubia (Hoffm.) Lettau

Physciaceae; 4, 5, 6, 7 (Sa); Published data in NW Africa: Alg, Serradj \& al. (2013); Bendaikha (2006); Egea \& Llimona (1991); Haina \& Bendechach (2004); Hamralaine (2007, 2013); Semadi (1989); Tun, El Mokni \& al. (2015); Mor, Ajaj \& al. (2013).

Physcia stellaris (L.) Nyl.

Physciaceae; 1, 3, 4, 7, 8, 9 (Co); Published data in NW Africa: Alg, Khedim \& al. (2018); Boutabia (2000); Haina \& Bendechach (2004); Hamralaine (2013); Tun, Seaward (1996); Mor, Ajaj \& al. (2013).

Physcia tenella (Scop.) DC.

Physciaceae; 3, 4, 5, 8, 9 (Co); Published data in NW Africa: Alg, Khedim \& al. (2018); Ait Hammou \& al. (2011); Bendaikha (2006); Boutabia (2000); Djellil (1989); Egea \& al. (1990); Egea (2003); Fadel \& al. (2012); Flagey (1896); Haina \& Bendechach (2004); Hamralaine (2007, 2013); Khedim (2012); Mosbah (2007); Rahali (2003); Semadi (1989); Slimani \& al. (2013); Tun, Seaward (1996), El Mokni \& al. (2015); Mor, Ajaj \& al. (2013).

Physcia tribacia (Ach.) Nyl.

Physciaceae; 3, 5, 7 (Co, Sa); Published data in NW Africa: Alg, Ait Hammou \& al. (2011); Hamralaine (2013); Mor, Ajaj \& al. (2013).

Physconia detersa (Nyl.) Poelt

Physciaceae; 5 (Co); Published data in NW Africa: Alg, Khedim \& al. (2018); Dubuis \& Faurel (1945); Flagey (1896); Haina \& Bendechach (2004); Mor, Ajaj \& al. (2013).

Physconia grisea (Lam.) Poelt

Physciaceae; 3, 4, 5, 7 (Co); Published data in NW Africa: Alg, Bouly de Lesdain (1939);

Boutabia (2000); Alonso \& Egea (2003); Fadel \& al. (2012); Flagey (1896); Haina \& Bendechach (2004); Hamralaine (2013); Mosbah (2007); Rahali (2003); Semadi (1989); Tun, El Mokni \& al. (2015); Mor, Ajaj \& al. (2013).

Physconia perisidiosa (Erichs.) Moberg

Physciaceae; 1, 5, 9 (Co, Mu); Published data in NW Africa: Alg, Khedim \& al. (2018); Alonso \& Egea (2003); Hamralaine (2013); Haina \& Bendechach (2004); Semadi (1989); Tun, Seaward (1996); Mor, Ajaj \& al. (2013).

* Physconia distorta var. subvenusta Cromb.

Physciaceae; 4, 6 (Co); No data published in NW Africa.

Pseudevernia intensa (Nyl.) Hale \& W.L. Culb.

Parmeliaceae; 4, 6, 7 (Co); Published data in NW Africa: Alg, Haina \& Bendechach (2004); Hamralaine (2013). No data published in Morocco and Tunisia. 


\section{Ramalina canariensis Steiner}

Ramalinaceae; 4, 5 (Co); Published data in NW Africa: Alg, Serradj \& al. (2013); Djellil (1989); Haina \& Bendechach (2004); Hamralaine (2013); Semadi (1989); Slimani \& al. (2013); Tun, Seaward (1996), El Mokni \& al. (2015); Mor, Ajaj \& al. (2013).

Ramalina farinacea (L.) Ach.

Ramalinaceae; 2, 3, 4, 6, 7, 8 (Co); Published data in NW Africa: Alg, Khedim \& al. (2018); Serradj \& al. (2013); Alonso \& Egea (2003); Flagey (1896); Haina \& Bendechach (2004); Hamralaine (2013); Khedim (2012); Rebbas \& al. (2011); Slimani \& al. (2013); Werner (1940, 1949); Tun, Seaward (1996), El Mokni \& al. (2015); Mor, Ajaj \& al. (2013).

Ramalina fastigiata (Pers.) Ach.

Ramalinaceae; 1, 2, 4, 6, 8, 9 (Co); Published data in NW Africa: Alg, Khedim \& al. (2018); Serradj \& al. (2013); Alonso \& Egea (2003); Flagey (1896); Haina \& Bendechach (2004); Hamralaine (2013); Khedim (2012); Rebbas \& al. (2011); Slimani \& al. (2013); Werner (1940, 1949); Tun, Seaward (1996), El Mokni \& al. (2015); Mor, Ajaj \& al. (2013).

Ramalina celastri (Sprengel) Krog \& Swinscow

Ramalinaceae; 5, 6, 7 (Co); Published data in NW Africa: Alg, Ait Hammou \& al. (2011); Hamralaine (2013). No data published in Morocco and Tunisia.

Ramalina reagens (B. de Lesd.) W.L. Culb.

Ramalinaceae; 4, 5 (Co); Published data in NW Africa: Alg, Khedim \& al. (2018); Tun, Seaward (1996); El Mokni \& al. (2015); Mor, Ajaj \& al. (2013).

Usnea florida (L.) F.H. Wigg.

Parmeliaceae; 2, 4 (Co); Published data in NW Africa: Alg, Flagey (1896); Haina \& Bendechach (2004); Nylander (1854); Trabut (1928); Mor, Ajaj \& al. (2013).

Xanthoparmelia conspersa (Ehrh. ex Ach.) Ach.

Parmeliaceae; 3, 6, 9 (Sa); Published data in NW Africa: Alg, Ali Ahmed \& al. (2018), Amrani \& al. (2018); Tun, El Mokni \& al. (2015).

Xanthoria fallax (Hepp)

Teloschistaceae; 1, 4, 6, 8 (Co, Sa); Published data in NW Africa: Alg, Hamralaine (2007);

Tun, El Mokni \& al. (2015); Mor, Ajaj \& al. (2013).

Xanthoria parietina (L.) Ach.

Teloschistaceae; 1, 2, 3, 4, 5, 6, 7, 8, 9 (Co, Sa); Published data in NW Africa: Alg, Khedim \& al. (2018); Boutabia (2000); Fadel \& al. (2012); Hamralaine (2007, 2013); Khedim (2012); Tun, Seaward (1996), El Mokni \& al. (2015); Mor, Ajaj \& al. (2013).

\section{Floristic richness}

Field investigations lead us to sample 532 phorophyts "trees" at the 8 stations visited across the Tessala Mountains. It allowed identifying in total 53 lichen taxa growing in this region. These taxa belong to 16 different families dominated by Physciaceae (16 species), Parmeliaceae and Lecanoraceae (8 species each).

Although the number of 53 lichens may seem interesting for a region with a predominantly semi-arid bioclimate (Saidi 2017), the great part of these species are nitrophityc, or ubiquists lichens, generally distributed (Roux \& al. 2017). Indeed, this flora is strongly masked by foreign elements of mainly temperate origin. The temperate element, which arrived before, at the 
time of the glaciations or after, is substantially equal in the three territories (Algeria, Morocco and Tunisia), although at a slightly higher percentage in Algeria (Werner 1955).

Otherwise, this number is much important than that reported by Ait Hammou \& al. (2013) for green oak lichens in the semi-arid region of Tiaret (29 species).

\section{Chorology and biogeography}

The analysis of the obtained data following this research allowed us to identify 3 species that we report for the first time to NW Africa. These are the following taxa: Lecanora praesistens, Multiclavula vernalis and Physconia distorta var. subvenusta. These reports indicate first of all the richness of the lichen flora of Algeria, but also the fact that the Algerian lichen flora is poorly known (Khedim \& al. 2018).

\section{Comments on some interesting species}

Several species in our list are listed either for the first time in NW Africa (Lecanora praesistens, Multiclavula vernalis, Physconia distorta var. subvenusta) or they are cited only in Algeria and missing in neighboring countries (Amygdalaria continua, Buellia coniops, Candelariella superdistans, Flakea papillata, Lecidea exigua, Lichenomphalia umbellifera, Intense Pseudevernia and Ramalina celastri).

Lecanora praesistens is a corticolous lichen on deciduous or coniferous trees, in moderately humid, well-lit and sunny biotopes. It is characterized by ellipsoid spores, simple, colorless, $12-16,10-17 \times 6-9 \mu \mathrm{m}$. In the thallin rim are large crystals clearly visible in polarized light and soluble in $\mathrm{N}$ but not in $\mathrm{K}$. It differs from L. chlarotera Nyl. present in Tunisia and Morocco (Seaward \& al. 1996; Ajaj \& al. 2013) which shows only eight spores, coarse crystals in epithecium, large crystals in the thallin ( $\mathrm{P}-)$ edge of apothecia. Lecanora allophana Nyl . and L. pulicaris (Pers.) Ach. reported both in Morocco (Ajaj \& al. 2013) are distinguished from L. praesistens by the fact that the first has eight spores, an epithecium devoid of crystals, small crystals in the thallin ( $\left.\mathrm{P}_{-}\right)$edge of apothecia, then that the second also has fine crystals in the epithecium but the spores are eight, and the thallin edge of the apothecia is most often ( $\mathrm{P}+$ ) red (AFL 2019).

Multiclavula vernalis is one of a relatively small number of lichen-forming basidiomycetes, i.e. fungi that incorporate cells of a green alga within their tissues. The species remains to be searched in neighboring countries. The genus Multiclavula has not been quoted before in Algeria, Morocco and Tunisia.

Physconia distorta var. subvenusta is distinguished from P. distorta (With.) J. R. Laundon by its apothecia with lobules; the underside of the lobes is black as in P. distorta; in P. venusta (Ach.) Poelt, the underside of the lobes is white.

Amygdalaria continua is a species characterized by a continuous thallus with a finely smooth, rarely cracked or cracked texture, usually thick brownish gray with black tips. It can be recognized by the absence of soredia or by Apothecia entirely immersed, sunk in the thallus and no chemical staining (K-, C-, KC-, P-). It differs from Amygdalaria consentiens var. consentians with a cracked and cracked thallus and Amygdalaria consentiens var. japonica with a cracked thallus containing stictic and constictic acidss (Brodo \& Hertel 1987). According to Amrani \& al. (2018), A. continua is one of the taxa cited in the literature for Algeria with erroneous or doubtful records unsupported by herbarium material. But here we confirm his presence in our country. Genus and 
species do not appear in the lists published in the neighboring countries including Seaward \& al. (1996) and Ajaj \& al. (2013).

Buellia coniops is a calcareous lichen, but can be found on non-calcareous (mainly granitic) rocks on the seacoasts. It is acidophilic, nitrophilous and halophilic (Roux \& al. 2017). It has spores 1 times septated with uniformly thick, finely punctuated walls, 13-18 $\times$ $7-9 \mu \mathrm{m}$. This species is to be distinguished from B. atrocinerella (Nyl.) reported in Morocco (Ajaj \& al. 2013) which has spores by 8, brown, uniseptated, 14.9-18 x 9.5-10.8 $\mu \mathrm{m}$.

With its small, scattered yellow fruits (no hint of orange) and an inapparent thallus, Candelariella superdistans appears superficially similar to C. aurella (Hoffm.) Zahlbr. present in Morocco and Tunisia (Seaward \& al. 1996; Ajaj \& al. 2013), but that species has a paraplectenchymatous thalline margin without protruding hyphae.

A few years after the description of Flakea papillata in 1992, the species was included in the genus Agonimia by Aptroot \& al. (1997), but the molecular data of Muggia \& al. (2010) show that the taxon should be kept in a separate genus. F. papillata differs from other Agonimia species by its thallus structure. These are usually squamous-leper (Eriksson 1992, Perlmutter 2006). This species remains to be found in the two neighboring countries.

The epithecium of Lecidea exigua is highly charged with crystals is very similar to Lecidella elaeochroma found in Morocco and Tunisia (Seaward \& al. 1996; Ajaj \& al. 2013) but apothecia and spores are smaller and especially narrower.

Lichenumphalia umbilefera is a basidiolochen with a granular, green, conspicuous thallus; the granules are agglomerates of algae (Coccomyxa) traversed by thick-walled hyphae (AFL, 2019). The species has only been indicated in Algeria (Khedim \& al. 2018) and remains to be searched in neighboring countries. So far, there is no other species of the genus Lichenumphalia in NW Africa.

Pseudevernia intensa is characterized by a thallus sometimes exceeding $10 \mathrm{~cm}$ in length, often during, formed of 2-5 mm wide, branched strips, with a greyish upper surface and a black underside, canaliculate, with curved edges. This thallus has a dorsiventrale organization (like the foliaceous) and no isidies on its upper face. Coloring: K-, KC-, P-, $\mathrm{C}+$. Pseudovernia furfuracea (L.) Zopf .Beih.Bot is a close species present in Morocco and Tunisia (Seaward \& al. 1996; Ajaj \& al. 2013) and shares the same morpholigic characteristics, but only the thallus does not stain $\mathrm{C}$-, in addition to the presence of isidies (Roux, 2017).

Ramalina leptocarpha Tuck. might be confused with $R$. celastri that differs in having flat laciniae, a convex apothecial disc without pruina, lacking pseudocyphellae on the margins and never producing zeorin. In addition, blades of $R$. leptocarpha produce apothecia on both sides, but they are usually characteristically found on upper side of blades in $R$. celastri. In addition, $R$. leptocarpha looks like $R$. calicaris (L.) Fr., a European species present in Morocco and Tunisia (Seaward \& al. 1996; Ajaj \& al. 2013) that differs in having more protruded pseudocyphellae.

\section{Conservation and conclusion}

Of the lichens identified in this study, 17 taxa (Amygdalaria continua, Evernia prunastri, Hypogymnia physodes, Phlyctis argena, Physcia adscendens, Physcia biziana, Physcia 
aipolia, Physcia caesia, Physcia dubia, Physcia stellaris, Physcia tenella, Physconia grisea, Physconia perisidiosa, Physconia distorta var. subvenusta, Ramalina canariensis, Ramalina farinacea, Ramalina fastigiata) are officially protected in Algeria (Radp 2012). They represent the $16 \%$ of all protected species in the country. This percentage indicates the importance of the lichen flora of the Tessala Mountains region. This flora seems to shelter a very significant and original lichen diversity which deserves to be protected against the different anthropic constraints. Indeed, the natural habitats of this region, especially the original vegetation of green oak covering these mountains remain very weakened and vulnerable because of a very important anthropic activity putting this floristic and ecological wealth in potential danger (Saidi 2017). Only by the presence of this large number of protected lichens by Algerian law, this region must have an official protection status. That is why we propose that the Tessala Mountain forest be granted the status of a natural reserve in order to conserve this biodiversity.

\section{References}

AFL (Association française de Lichénologie). 2019: http://www.afl-lichenologie.fr/. [Last Accessed 1 March 2019].

Ait Hammou, M., Maatoug, M. \& Hadjadj-Aoul, S. 2008: Contribution to the determination of the lichens in the Forest Pines in Tiaret area (Algeria). - Damascus Univ. J. Agric. Sciences 24(2): 289-303.

-, Hadjadj-Aoul, S., Miara, M. D. \& Zerrouki, D. 2011: Aspects taxonomiques des lichens du pin d'Alep (Pinus halepensis) et de cyprès (Cupressus sempervirens) de la forêt de Guezoul (Tiaret, Algérie). - Rev. Ecol. Environ. 7: 15-26. https://doi.org/10.1007/s10298-013-0789-3

—, Miara, M. D., Hadjadj-Aoul, S., Khedim, R. \& Safa, O. 2013: Inventaire des lichens du chêne vert (Quercus rotundifolia) de la forêt communale Guezoul de Tiaret. - Rev. Ecol. Environ. 9: 10-16.

—, 一, Rebbas, K., Slimani, A., Ravera, S. \& Hamrlaine, A. S. 2014: Mise à jour de l'inventaire des lichens d'Algérie. - Rev. Ecol. Environ. 10: 75-103.

Ajaj, A., Ouazzani-Touhami, A., Benkirane, R. \& Douira, A. 2013: Contribution to the update catalogue of lichenized and lichenicolous fungi in Morocco. - J. Anim. Plant. Sci. 19(3): 2961-3025.

Ali Ahmed, M., Brakni, R. \& Hamel, T. 2018: Lichen diversity in the Edough Peninsula, North East of Algeria. - Bot. Complut. 42: 9-18. http://dx.doi.org/10.5209/BOCM.61381

Alonso, F. L. \& Egea, L. M. 2003: Hongos liquenizados y liquenicolas epífitos de algunas localidades costeras de Argelia y Túnez. - Anal. Biol. 25: 73-79.

Amrani, S., Nacer, A., Noureddine, N. E. \& Seaward, M. R. D. 2015: Lichenological exploration of Algeria: historical overview and annotated bibliography, 1799-2013. - Willdenowia 45(1): 15-34. https://doi.org/10.3372/wi.45.45102

—, Seaward, M. R. D., Sipman, H. J. M. \& Feuerer, T. 2018: Lichenological exploration of Algeria II: checklist of lichenized, lichenicolous and allied fungi. - Herzogia 31: 817-892. https://doi.org/10.13158/heia.31.2.2018.817

Aptroot, A. 2009: Keys to the macrolichens and checklist of the lichens and lichenicolous fungi of New Guinea. - Utrecht

— \& Schumm, F. 2008: Key to Ramalina species known from Atlantic islands, with two new species from the Azores. - Sauteria 15: 21-57.

—, Diederich, P., Sérusiaux, E. \& Sipman, H. J. M. 1997: Lichens and lichenicolous fungi from New Guinea. - Biblioth. Lichenol. 64: 1-220. https://doi.org/10.2307/3244377 
Bendaikha, Y. 2006: Les lichens de la région d'Oran: Systématique et application à la qualité de l'air atmosphérique. - Magister thesis, Univ. Oran Es-Sénia.

Boistel, A. 1986: Nouvelle Flore des Lichens pour la détermination facile des espèces. - Paris.

Bouiadjra, S. E. E., Zerey, E. \& Benabdeli, K. 2011: Étude diachronique des changements du couvert végétal dans un écosystème montagneux par télédétection spatiale: cas des monts du Tessala (Algérie occidentale). - Physio-geo 5: 221-225. https://doi.org/10.4000/physio-geo.2048

Bouly de Lesdain, M. 1907: Notes lichénologiques VII. - Bull. Soc. Bot. France 54: 442-446. https://doi.org/10.1080/00378941.1907.10831289

— 1911: Lichens du Sud algérien recueillis par M. Seurat. - Bull. Soc. Hist. Nat. Afrique 3: 95-98.

- 1939: Notes lichénologiques XXXI. - Bull. Soc. Bot. France 86: 81-84.

Boutabia, L. 2000: Dynamique de la flore lichénique corticole sur Quercus suber L. au niveau du Parc national d'El Kala. - Magistere Thesis. Univ Annaba, Algeria.

Brodo, I. M. \& Hertel, H. 1987: The lichen genus Amygdalaria porpidiaceae in North America. Herzogia 7(3-4): 493-522.

Brongniart, C. 1882: Excursion dans l'Atlas. - Compt. Rend. Assoc. Franç. Avancem. Sci. 10: 1084-1091.

Clauzade, G. \& Roux, C. 1984: Les genres Aspicilia Massal. et Bellemerea Hafellner \& Roux. Bull. Soc. Bot. Centre-Ouest 15: 127-141.

Desfontaines, R. 1798-1799: Flora atlantica, sive historia plantarum, quae in Atlante, agro tunetano et algeriensi crescunt, 2. - Paris. https://doi.org/10.1017/cbo9781139644921

Djebar, I. \& Fradjia, L. 1992: Etude phytosociologique et systématique de la flore lichénique corticole du parc national d'EL KALA (Application d'une méthode combinée entre les méthodes : classique, partielle et intégrale). - Ingeneer thesis. Univ. Annaba, Algérie.

Djellil, S. 1989: Étude de la flore lichénique du massif forestier d'Akfadou et Béni Ghorbi. Magistere thesis. Univ. Tizi-Ouzou, Algeria.

Dubuis, A. \& Faurel, L. 1945: Note sur quelques espèces nouvelles ou intéressantes pour la flore du Djurdjura. - Bull. Soc. Hist. Nat. Afrique 36: 12-22.

Durieu de Maisonneuve, M. C. \& Montagne, J. P. 1846: Exploration scientifique de l'Algérie. - Sci. Nat. Bot. Lichens: I Cryptog. 1: 198- 295.

Egea, J. M. 1996: Catalogue of lichenized and lichenicolous fungi of Morocco. - Bocconea 6: 19-114.

— \& Llimona, X. 1991: Phytogeography or siliclcolous lichens in Mediterranean Europe and NW Africa. - Bot. Chron. 10: 179-198.

Egea, J. M., Torrente, P. \& Rowe, J. G. 1990: Contribucion a la flora de Argelia y Tunez: liquenes y hongos lichenicolas. - Cryptogamie, Bryol. Lichenol. 11(4): 409-417.

El Mokni, R., Boutabia, L., Sebei, H. \& El-Aouni, M. H. 2015: Species richness, distribution, bioindication and ecology of lichens in oak forests of Kroumiria, North West of Tunisia. - J. Bio. \& Env. Sci 7(2): 32-60. https://doi.org/10.1127/nova_hedwigia/2018/0494

Eriksson, O. E. 1992: Psoroglaena cubensis and Flakea papillata gen. et sp. nov., two corticolous lichens with a pantropical distribution. - Syst. Ascomycetum 11: 11-27.

Esnault, J. 1985: Le genre Aspicilia Mass. (Lichens) en Algérie: étude des caractères taxonomiques et de leuvariabilité. - Phd thesis, Université de Rennes I.

— \& Roux, C. 1987: Amygdalaria tellensis (lichens), nouvelle espèce du Tell Algérien. - Anal. Jard. Bot. Madrid 44(2): 211-225.

Fadel, D., Dellal, A., Damel, R. \& Laifa, A. 2012: Bioestimation de la pollution atmospherique globale d'une ville du nord Est Algeirien (Sikda) par la méthode de l'indice de pureté atmosphérique. - Ecol. Environ. 8: 59-74. https://doi.org/10.4267/pollution-atmospherique.1414

Faurel, L., Ozenda, P. \& Shcotter, G. 1951: Matériaux pour la flore lichénologique d'Algérie et de la Tunisie. Caliciaceae, Cypheliaceae, Peltigeraceae, Pertusariaceae. - Bull. Soc. Hist. Nat. Afr. Nord 42: 62-112. 
—, — \& - 1953: Notes lichénologiques Nord africaines III - Quelques lichens d'Afrique du Nord nouveaux, rares ou peu connus. - Bull. Soc. Hist. Nat.Afrique Nord 44: 367-384.

Flagey, C. 1891: Lichenes Algerienses. - Rev. Mycol. (Toulouse) 49: 83-117.

- 1892: Lichenes Algériennes Exsiccati. - Rev. Mycol. (Toulouse) 53: 70-79.

- 1895: Lichenes algerienses. - Rev. Mycol. (Toulouse) 56 : 101-115.

- 1896: Catalogue des lichens d'Algérie. - Pp. 1-140 extract from: Battandier, J. \& Trabut, L. (eds), Flore de l'Algérie, 3(1, 1). - Alger.

Freka-Zazou, N. 2006: Impact de l'occupation spatio-temporelle des espaces sur la conservation de l'écosystème forestier Cas de la commune de Tessala, wilaya de Sidi Bel Abbés, Algérie. Magister thesis. Univ. Tlemcen.

Gounot, M. 1969: Méthodes d'étude quantitative de la végétation. - Paris.

Guttová, A., Vondrák, J., Schultz, M. \& El Mokni, R. 2015: Lichens collected during the 12th "Iter Mediterraneum" in Tunisia, 24 March - 4 April 2014. - Bocconea 27: 69-77. https://doi.org/10.7320/bocc27.1.069

Haina, N. \& Bendechach, S. 2004: Etude des lichens en Algerie. - DES thesis. Ecole Normale Superieur Vieux-Kouba (Alger).

Hale, M. E. 1990: A synopsis of the lichen genus Xanthoparmelia (Vainio) Hale (Ascomycotina: Parmeliaceae). - Smithsonian Contr. Bot. 74: 1-250. https://doi.org/10.5479/si.0081024x.74

Haluwyn, C. V., Asta, J. \& Gavériaux, J. P. 2009: Guide des lichens de France, lichens des arbres. - Paris. -, 一, Boissière, J. C. \& Clerc, P. 2012: Guide des lichens de France, lichens des sols. - Paris.

Hamralaine, A. S. 2007: Contribution à l'étude des lichens corticoles associés au Juniperus oxycedrus du Djbel Guezzoul de Tiaret : Inventaire et valorisation. - Ingénieer thesis. Univ. Tiaret, Algérie.

— 2013: Inventaire des lichens épiphytes des monts de Tessala: Aspect appliqué pour l'évaluation de la qualité de l'air de la ville de Sidi Bel Abbés (Algérie occidentale). - Magister thesis. Univ. Tiaret, Algérie.

Hertel, H. 1971: Beiträge zur Kenntnis der Flechtenfamilie Lecideaceae IV. - Herzogia 2: 231-261. —. 1987: Lecideaceae exsiccatae: Fasc. IX (No. 161 -180). - München.

Jahns, H. M. 2007: Flore murale de la ville de Tlemcen (province d'Oran). - Alger.

Jourdan, P. 1867: Flore murale du tombeau de la chrétienne (Province d'Alger). - Paris.

Khedim, R. 2012: Contribution à l'étude de la flore lichénique épiphyte du Parc National de Theniet el-Had (Tissemsilt, Algérie). - Magister thesis. Unv. Tiaret.

—, Ait Hammou, M. \& Maatoug, M. 2013: Importance de l'éco-conscience dans la preservation des écosystèmes forestiers, cas du Parc National de Theniet El Had (Tissemsilt, Algérie) [In Arabic]. - Rev. Ecol. Environ. 9: 66-72.

—, Maatoug, M., Benhassaini, H. \& Ait Hammou, M. 2018: Macrolichens new to Algeria and other interesting species from Theniet-el-Had National Park. - Herzogia 31(1): 252-267. https://doi.org/10.13158/099.031.0121

Kirschbaum, U. \& Wirth, V. 1997: Les Lichens bio-indicateurs, les reconnaître, évaluer la qualité de l'air. - Traduit de l'allemand et adapté par l'AFL (Haluwyn, V. C., Gavériaux, J.-P., Cuny, D. \& Lerond, M.). - Paris.

Krzewicka, B., García, M. A., Johansen, S. D., Sancho, L. G. \& Martín, M. P. 2009: Morphological and nuclear ribosomal DNA data support distinguishing two new species of Umbilicaria (Umbilicariaceae, Ascomycota) from Europe. - Lichenologist 41(6): 631-648. https://doi.org/10.1017/S0024282909990120

Leuckert, C., Poelt, J. \& Hähnel, G. 1977: Zur Chemotaxonomie der eurasischen Arten der Flechtengattung Rhizoplaca. - Nova Hedwigia 28: 71-129.

Maheu, J. 1928: Contribution à la Lichénographie du Rif (Maroc). - Cavanillesia 1: 54-59.

Maire, R. \& Senevet, G. 1928: Flore murale du Tombeau de la Chrétienne. - Bull. Soc. Hist. Nat. Afrique N. 19: 23-28. 
Merabti, K. 2008: Utilisation des lichens comme indicateurs biologiques de la pollution atmosphérique dans la région est d'Alger. - Magister thesis. Univ. Annaba.

Mosbah, B. 2007: Étude comparative de la dynamique de la flore lichénique corticole sur Quercus ilex L et Pistacia atlantica Desf. au niveau du Djebel Sidi R'ghis - Oum El Bouaghi. Ingeneer thesis. Univ. Oum el Bouagi.

Montagne, C. 1838: Cryptogames algériennes, ou plantes cellulaires recueillies par M. Roussel aux environs d'Alger, et publiées. - Ann. Sci. Nat., Bot., sér. 2, 10: 268-279.

Muggia, L., Zellnig, G., Rabensteiner, J. \& Grube, M. 2010: Morphological and phylogenetic study of algal partners associated with the lichen-forming fungus Tephromela atra from the Mediterranean region. - Symbiosis 51: 149-160. https://doi.org/10.1007/s13199-010-0060-8

Nylander, W. 1854: Etude sur les lichens de L'Algérie. - Mém. Soc. Sci. Nat. Cherbourg 2: 305-344.

Ozenda, P. \& Clauzade, G. 1970: Les lichens: étude biologique et flore illustrée. - Paris.

Perlmutter, G. B. 2006: Lichen Inventory of the North Carolina Piedmont. - Castanea 71(4): 282294. https://doi.org/10.2307/3241854

Radp. 2012: Décret exécutif n ${ }^{\circ} 12-03$ du 4 janvier 2012 fixant la liste des espèces végétales non cultivées protégées. - J. Off. Rép. Algérienne Démocratique Populaire 3: 12-39.

Rahali, M. 2003: Etude de la pollution plombique et globale dans la région d'Alger, en utilisant les lichens comme indicateur biologiques. - Doct thesis. Institut National d'Agronomie, Alger.

Rebbas, K., Boutabia, L., Touazi, Y., Gharzouli, R., Djellouli, Y. \& Alatou, D. 2011: Inventaire des lichens du Parc national de Gouraya (Béjaïa, Algérie). - Phytothérapie 9(4): 225-233. https://doi.org/10.1007/s10298-011-0628-3

Reichert, I. 1937: La position phytogéographique de l'Afrique du Nord au point de vue lichénologique. - Bryol. Lichénol 13: 10-22. https://doi.org/10.1080/00378941.1936.10834041

Roux, C. 1990: Échantillonnage de la végétation lichénique et approche critique des méthodes de relevés. - Cryptog. Bryol. Lichénol. 11(2): 95-108.

- (ed.) 2017: Catalogue des lichens et champignons lichénicoles de France métropolitaine, 2e édition revue et augmentée. - Fontainebleu: Association française de lichénologie.

Saidi, B. 2017: Dynamique de la phytodiversité dans les monts de tessala (Algerie occidentale). Doct thesis. Univ Sidi Belabess.

Schwarz, W. 1976: Ökophysiologische Untersuchungen in den Bergen der zentralen Sahara. - Ber. Naturwiss. Med. Vereins Innsbruck 63: 139-164.

Seaward, M. R. D. 1996: Checklist of Tunisian lichens. - Bocconea 6: 115-148

Semadi, A. 1989: Effet de la pollution atmosphérique (pollution globale, Fluorée et plombique) sur la végétation dans la région d'Annaba. - Doct thesis. Univ Pierre et Marie Curie (Paris 6).

—, Tahar, A., Fadel, D. \& Benoit-Guyod, J. L. 1997: The behaviour of some lichen species in Annaba area (Algeria). - Synth. Rev. Sci. Technol. 2: 17-24.

Serradj Ali Ahmed, M., EL Oualidi, J., Slimani, A. \& Boumedris, Z. 2013: Contribution to the lichens inventory hens from the Oubeira lake Ubeira (NE Algeria). - Bull. Inst. Sci. Rabat 35: 15-17.

Sérusiaux, E., Diederich, P. \& Lambinon, J. 2004: Les macrolichens de Belgique, du Luxembourg et du Nord de la France: Clés de détermination. - Luxembourg. https://doi.org/10.1002/fedr.19800910107

Slimani, A. R., Serradj, M., Hamel, T. \& Coste, C. 2013: Contribution à l'étude de la flore lichénique dans la zéenaie de Bougous (forêt de Ramel Toual) au niveau du Parc Nationale d'El Kala Nord-Est Algérien. - Rev. Sci. Technol. Synthèse 27: 22-29.

Steiner, J. 1902: Sweiter Beitrag zur Fleichtenflora Algiers. -Verh. K. Zool-Bot Gesellsch. Wien 52: 469-487.

Trabut, L. C. 1887: D’Oran à Mécheria - Catalogue des plantes remarquables. - Alger.

Werner, R. G. 1931: Contribution à la flore cryptogamique du Maroc II. - Bull Soc Hist. Nat. Afr. Nord 22: 93-102. 
- 1938: La plasticité écologique des Cryptogames méditerranéens. - Bull. Soc. Bot. France 85: 496-499. https://doi.org/10.1080/00378941.1938.10834117

- 1940: Contribution à la flore cryptogamique de l'Algérie et de la Tunisie. - Bull. Soc. Sci. Nat. du Maroc 20: 113-121.

- 1949: Les origines de la flore lichénique de l'Algérie d'après nos connaissances actuelles. - Alger.

- 1955: Synthèse phytogéographique de la flore lichénique de l'Afrique du Nord française d'après les données récentes et essai de paléogéographie lichénique. - Bull. Soc. Bot. France 102: 35 50. https://doi.org/10.1080/00378941.1955.10835052

White, F. 1986: La végétation de l'Afrique. Mémoire accompagnant la carte de végétation de l'Afrique. - UNESCO/AETFAT/UNSO. Rech. sur les Ress. Nat., ORSTOM/ UNESCO.

Zahlbruckner, A. 1904: Lichenes oranenses hochreutinerani. - Pp. 244-247 in: Hochreutiner, B. P. G., Le Sud Oranais. Études floristiques et phytogéographiques faites au cours d'une exploration dans le sud-ouest de l'Algérie en 1901. - Ann. Conserv. Jard. Bot. Genève 7-8: 22-276. https://doi.org/10.4095/297153

Zablbruckner, A. 1930-1931: Catalogus Lichenum Universalis 7: 784.

Zouaoui, S. 1989: Étude de la flore lichénique du massif forestier Akfadou et Beni-Ghobri. - Tizi Ouzou. - Magistere thesis, Univ. Tizi Ouzou, Algeria.

Addresses of the authors:

Hamralaine Ali Samir ${ }^{1}$, Benhassaini Hachemi ${ }^{2}$, Miara Mohamed Djamel ${ }^{1}$, Ait Hammou Mohammed ${ }^{1}$ \& Hamralaine Oussama ${ }^{1}$,

${ }^{1}$ Faculty of nature and life Sciences, Ibn Khaldoun University, Tiaret, Algeria. Emails: ecosamir@gmail.com; ecoreve@yahoo.fr; m-ait-hammou@hotmail.com

${ }^{2}$ Faculty of science of the environment, University Djillali Liabes, Sidi Belabbès, Algeria.

*Corresponding author: Miara Mohamed Djamel. E-mail: miara14130@yahoo.fr 
